\title{
PERSÉFONE, O FOLCLORE, O NÓ
}

\section{Larissa Costa da Mata}

RESUMO: Este ensaio se propõe a investigar a presença do verde e da primavera - ou seja, do mito de Perséfone - nos textos de Mário de Andrade, especialmente por meio de seu contato com o estudo 0 ramo de ouro (1890), de Sir James Frazer, bem como do desdobramento da concepção de verde em intelectuais como Georges Bataille, Carl Einstein, André Gide e Victoria Ocampo. A leitura da obra de Frazer forneceu a principal matéria para os estudos de Andrade sobre o foldore, tais como as Danças dramáticas do Brasil (1959), e para a tentativa de se transformar esse saber em uma disciplina. 0 verde em Andrade, como veremos, demonstra uma interpretação da sobrevivência como a permanência de um elemento fixo e originário, e do povo como passível de ser representado pela forma.

PALAVRAS-CHAVE: Mário de Andrade. Folclore. Verde.

\section{PERSEPHONE, FOLKLORE, KNOT}

ABSTRACT: This essay aims to investigate the traces of 'green' and Spring - that is, the myth of Persephone - on a few texts by Mário de Andrade, especially by means of his contact with The Golden Bough (1890), by sir James Frazer, as well as the developments of a conception of 'green' in intellectuals such as Georges Bataille, Carl Einstein, André Gide and Victoria Ocampo. The Golden Bough has given the main substance to Andrade's studies on Folklore, as the Brazilian Dramatic Dances (1959), and to his attempt to transform Folklore into a subject. As we may see, Andrade's interpretation of 'green' resulted in a perspective of survival as the permanence of a fixed and primary element, and of people subject to be represented by form.

KEYWORDS: Mário de Andrade. Folklore. Green.

Larissa Costa da Mata é doutora em Teoria da Literatura. Foi professora leitora de Estudos Brasileiros na Universidade de Pequim entre abril de 2013 e julho de 2014. 


\title{
PERSÉFONE, O FOLCLORE, O NÓ*
}

\author{
Larissa Costa da Mata
}

\begin{abstract}
O rouxinol pode ser substituído a) pela rosa, b) pelos seios, mas nunca pelas pernas, pois o rouxinol existe, precisamente, para que possamos evitar nomear os fatos. $O$ rouxinol pertence ao inventário dos desvios burgueses por meio dos quais procura-se sugerir coisas lascivas, mesmo quando aparentemente afasta-se delas. $O$ rouxinol é, possivelmente, também o signo da fadiga erótica.
\end{abstract}

Rouxinol, Carl Einstein

\section{PERSÉFONE}

A ninfa Perséfone, conhecida em Roma como Prosérpina, evoca o subterrâneo e o pútrido, mas também o constante florescer, a transformação do meio; sendo luz e sombra, nascimento e morte - segundo a leitura do mito por James Frazer, que, antes de dedicar-se à antropologia, preparara uma edição do livro Descrição da Grécia em $1884 .{ }^{1}$ Segundo Homero, citado em $O$ ramo de ouro (1890), Perséfone colhia flores quando foi levada por Plutão (ou Hades) ao inferno; a sua mãe, Deméter, ameaçou estragar a colheita até que a filha retornasse. $O$ deus cedeu à ameaça e decidiu entregá-la, contanto que ela deixasse o reino em jejum. ${ }^{2}$ No entanto, a jovem devorara sete caroços de romã e é denunciada por Ascaláfio, o que a impediu de partir definitivamente, salvo durante os meses da primavera (seis ou três, dependendo da versão). ${ }^{3}$ As interpretações do nascimento da primavera coincidem com duas concepções diversas da origem, uma que privilegia os seus retornos periódicos e a celebração do começo por meio da forma (a de Mário de Andrade, Victoria

\footnotetext{
* Uma versão mais breve e inicial deste texto foi apresentada no II Seminário dos Alunos do Programa de Pós-Graduação em Literatura da Universidade Federal de Santa Catarina e publicada nos Anais do evento em 2012.

${ }^{1}$ STOCKING, George Ward. After Tylor. British Social Anthropology (1888-1951). Madison: The University of Wisconsin Press, 1995.

2 FRAZER, James. The Golden Bough. A Study in Magic and Religion. New York: The Macmillan Company, 1945. (Abridged Edition)

${ }^{3}$ CASCUDO, Luís da Câmara. Superstição no Brasil. Belo Horizonte: Itatiaia, 1985.
} 
Ocampo e André Gide) e outra, de parentesco nietzschiano, que a compreende de acordo com o caráter de violência e de ruptura (a de Carl Einstein e Georges Bataille).

O interesse de Mário de Andrade por esse mito se dera antes mesmo de ter dado início à leitura de Frazer, no texto "Flor nacional", que compôs a coluna Táxi do Diário Nacional em 7 de janeiro de 1930. Em resposta a um concurso que pretendia determinar a rainha das flores brasileiras, o autor propõe a vitória-régia como símbolo do país, que represente qualquer indivíduo independentemente da região de nascimento. Encontrada na floresta latinoamericana (portanto, sem fronteiras e sem nação) a mesma fora, diga-se de passagem, contemplada por Richard e Robert Schomburgk, viajantes em busca de Eldorado, dos quais recebera essa denominação, de acordo com o escritor cubano Alejo Carpentier. ${ }^{4}$

A escolha de Andrade se sustenta no critério da beleza que, como esclarecerá mais tarde, predomina na arte desde os primórdios, na Grécia Antiga, que delimitou as necessidades espirituais do indivíduo e que, segundo ele em "O artista e o artesão", "é um ideal necessário à coletividade". ${ }^{5}$ Mesmo quando acompanhada pela inquietação, pelo seu oposto, a beleza não deixa de ser uma forma de ascensão à natureza e ao divino. Por essa razão, Andrade afirma que "primeiro foi a boniteza" que lhe chamou a atenção e, depois, a tranquilidade suscitada pelo calor e pela calmaria das águas onde repousava a flor, "aquele lagoão fechado em pleno mato, sem um risco de vento", como os Campos Elíseos, o paraíso da mitologia grega. ${ }^{6}$ Por sua pureza e pela superfície perfeita, a vitória-régia se apresenta como uma imagem uniforme que perfaz uma relação direta com o signo "flor", pois não nos recorda a estrutura de um repolho, como uma rosa, nem se assemelha a um espanador, como o cravo: "Não achei possível se comparar essa flor com outra nenhuma. Perfeição absoluta da forma, e principalmente flor que é declaradamente flor. A gente olha e diz: É flor. Não evoca imagem nenhuma." ${ }^{7} \mathrm{O}$ comentário se mostra, portanto, muito diverso da proposta de uma noção de "absoluto" pelo intelectual alemão Carl Einstein em suas colaborações na revista Documents,

${ }^{4}$ CARPENTIER, Alejo. Visão da América. Trad. Rubia P. Goldoni e Sérgio Molina. São Paulo: Martins Fontes, 2006.

${ }^{5}$ ANDRADE, Mário de. O baile das quatro artes. São Paulo: Livraria Martins, 1963, p. 22.

${ }^{6}$ Idem. Táxi e crônicas no Diário Nacional. Org. Telê Porto A. Lopez. São Paulo: Duas Cidades/Secretaria de Cultura, Ciência e Tecnologia, 1976, p. 183.

7 Ibidem, p. 184. 
como o verbete "Rouxinol". Para Einstein, o absoluto significava uma função não-metafísica e não-transcendental, que pode ser representada inadequada ou completamente como qualquer outra experiência, e permite ao artista e ao escritor uma invenção pura, não metafórica. ${ }^{8}$

Seguindo uma perspectiva que foi corrente entre os modernistas, a qual concebe a natureza a partir de um poder feminino ligado a um misto de sedução e de violência, a vitória-régia, para Mário de Andrade, manteria um elemento negativo submerso, os espinhos que ferem a mão no toque, e teria um perfume desagradável, somente perceptível quando nos aproximamos dela: "Mistura de mistérios, dualidade interrogativa de coisas sublimes e coisas medonhas, grandeza aparente, dificuldade enorme, o melhor e o pior ao mesmo tempo, calma, tristonha, ofensiva, é impossível a gente ignorar que nação representa essa flor." 9

Ao considerar que a impureza do nacional está oculta, Mário de Andrade não vai tão longe quanto Georges Bataille, quem levara ao extremo esse aspecto das fotografias de Karl Blossfeldt. As flores fálicas e grotescas, que acompanham "A linguagem das flores" (1929), nada indicam da beleza que Andrade encontrara na vitória-régia. Nesse texto, o qual também se encontra na revista Documents, Bataille recusa uma interpretação unívoca e alegórica da linguagem como Carl Einstein, ao denunciar uma associação contagiosa entre o órgão reprodutor das plantas e o romance, pois o que desperta o amor seria igualmente suscetível de evocar o riso. Desse modo, parece haver uma relação objetiva e inexplicável da flor com a beleza, a qual seria parcialmente verdadeira apenas para a corola, pois, ao murchar, toda ela se assemelha a um esterco. Como a parte superior se torna um sinal de paz, a visão dos campos e da floresta, contribui para o desenvolvimento das ideias de retidão e de justiça. No entanto, o que se revela pelo olhar também abriga, em si, o limite de qualquer lei, imposto pela moral ou pela razão. Por isso a parte baixa, voltada para o Hades ou para o inferno, procura a escuridão e demonstra, por sua vez, uma inclinação ao crime:

Não pode restar dúvida: a substituição das formas naturais pelas abstrações geralmente empregadas por filósofos parecerá não somente estranha, como ab-

${ }^{8}$ Cf. EINSTEIN, Carl. Rossignol. Documents, Paris, n. 2, p. 17-18, mai 1929; Idem, Revolution smashes through history and tradition. Trans. Charles W. Haxthausen. October, Cambridge, n. 107, p. 139-145, Winter 2004.

9 ANDRADE, Mário de. Táxi e crônicas no Diário Nacional, op. cit., p. 184. 
surda. É provável, e razoavelmente insignificante, que os próprios filósofos tenham recorrido várias vezes, ainda que com repugnância, a termos cujo valor deriva da produção dessas formas da natureza, como quando tratamos de baixeza. Não há cegueira que interfira quando se trata de defender as prerrogativas da abstração. Aliás, essa substituição pode levar-nos longe demais resultando, primeiramente, em um sentimento de liberdade, de livre disponibilidade de nós mesmos em todos os sentidos, absolutamente insuportável para a maioria. $\mathrm{E}$ também num desprezo inquietante por tudo o que ainda é, graças a míseros subterfúgios, elevado, nobre, sagrado [...]. ${ }^{10}$

Perséfone não se apazigua pela aparência, posto também poder ser compreendida como a emergência de uma força telúrica e dionisíaca que desabrocha imprevisivelmente, e não somente segundo os retornos cíclicos. A segunda leitura predomina no poema Persephone de André Gide, traduzido ao espanhol por Jorge Luís Borges para a revista Sur em $1936 .{ }^{11}$ A Perséfone de Gide é a origem, "a primeira manhã do mundo", a "embriaguez da manhã", o "raio nascente" e as "pétalas desbordando de licor", que reina diante da beleza de narciso, a flor entre os dois mundos. Levada por Hades ao reino das sombras para ser a noiva dele, a ninfa conhece a lentidão do tempo e a tristeza, enquanto se lembra dos sofrimentos e da espera do povo da terra. Nostálgica, ela devora a fruta granada, a romã (granada em espanhol, grenade em francês), o que a obriga a regressar somente na primavera, emergindo como a inocência vinda do inferno: "Cada gesto te solta e tua dança é um idioma que propaga o abandono, a confiança e a fortuna. $\mathrm{O}$ raio se promete à pétala da flor. Na natureza tudo ri e se sacia de luz. Tu saltas até o dia". ${ }^{12}$ Assim, Perséfone recupera, finalmente, o esplendor perdido das plantas, a semente que sempre germina, prospera e ri nos meses fecundos, no encontro com o povo que sofre (por sua ausência, pela violência vivida na Europa, da qual sua "fruta explosiva" seria um indício):

Teu destino é levar às sombras um pouco da claridade do dia, uma trégua aos seus incontáveis males, à sua miséria um pouco de amor. Se a primavera há de renascer, a semente deve resignar-se a morrer sob a terra, para reaparecer manhã em meses de ouro. ${ }^{13}$

\footnotetext{
${ }^{10}$ BATAILLE, Georges. Le langage des fleurs. Documents, Paris, n. 3, p. 164, 1929. Esta passagem e as demais citações em línguas estrangeiras foram traduzidas pela autora deste ensaio.

${ }^{11}$ GIDE, André. Persephone. Trad. Jorge Luis Borges. Sur, Buenos Aires, n. 19, p. 8-53, abr. 1936.

${ }^{12}$ Ibidem, p. 49.

${ }^{13}$ Ibidem, p. 53.
} 
Persephone fora musicado por Igor Stravinsky para o espetáculo de mesmo nome, representado em Buenos Aires e no Rio de Janeiro em 1936 e resenhado por Murilo Mendes para o jornal A Manhã. A intelectual argentina Victoria Ocampo recitara o texto de Gide no concerto e voltara-se, igualmente, aos mitos vegetais, comparando-se a Deméter ou Diana, a mãe da ninfa, na sua autobiografia. ${ }^{14}$ Mendes já não vira, na apresentação de 1936 , o arrebatamento telúrico, característico das obras anteriores de Stravinsky como a Sagração da primavera. Isso se tornaria notável, por exemplo, na leitura de Ocampo, de vitalidade pouco convincente: "A ilustre escritora argentina não cantava, não trilava, não enfunava o peito, não dava guinchos, o que evidentemente chateava a maioria do auditório, com saudades da Traviata, da Norma e de outras maravilhas parecidas". ${ }^{15}$

A ópera, como observara o artista Flávio de Carvalho em "Madona e Bambino", surge com um fenômeno religioso, antes mesmo da pintura sacra, encobrindo as emoções primitivas do homem e as potências do começo. Essa arte tem início com as primeiras missas cantadas das igrejas católicas, nas quais os homens utilizavam a música para manter cada vez mais serena a "fêmea", assemelhando-a à imagem da Virgem, cultuada na península itálica. ${ }^{16}$ Murilo Mendes aponta o mesmo sequestro da sexualidade no espetáculo. Para ele, Stravinsky havia conseguido fazer emergir na sinfonia da Sagração da primavera, fruto das pesquisas sobre o Oriente, um elemento primitivo, o qual se encontrava como uma força indomada pela civilização. No entanto, em Persephone, o bárbaro seria infelizmente eliminado pela cultura, e o arrebatamento dionisíaco substituído pela retidão apolínea, restando-nos somente a corola:

O elemento civilizador, entretanto, procura dominar o convite da destruição: já não mais dança de sangue, dança sexual, dança guerreira - mas Apolo consci-

\footnotetext{
${ }^{14}$ OCAMPO, Victoria; ALAYA, Francisco. Autobiografia. Madrid: Alianza Editorial, 1991.

${ }^{15}$ MENDES, Murilo. Formação de discoteca. São Paulo: Universidade de São Paulo, 1993, p. 86.

16 "É bem provável que o canto à vagina e a declamação lírica sejam anteriores à manifestação pictórica, mesmo porque semelhante canto pode perfeitamente pertencer a uma época que indicaria o início do uso das cordas vocais. Em todo caso, parece que os processos da história se repetem em outras escalas, observando-se, na Itália, que o período de grande desenvolvimento da ópera deu-se no século XVII na Europa, o que mostra que a ópera levou de um a dois séculos para contaminar a pintura. Um exame da iconografia da Virgem desde os primeiros séculos da era cristã, revela que no início a 'virgem' era uma mulher potente sem auréola, apenas uma representação simples do seu sexo [...]". CARVALHO, Flávio de. Os ossos do mundo. São Paulo: Antiqua, 2005, p. 126.
} 
ente da sua claridade, serenamente branco, conduz as Musas no balé inefável. A cultura venceu, polindo as armas espirituais para o combate em que surgem novas tendências e novas possiblidades de transformação e desdobramento do espírito humano e do seu "demônio" artístico - vida nova, ritmos novos, uma nova manifestação do Espírito do mundo. ${ }^{17}$

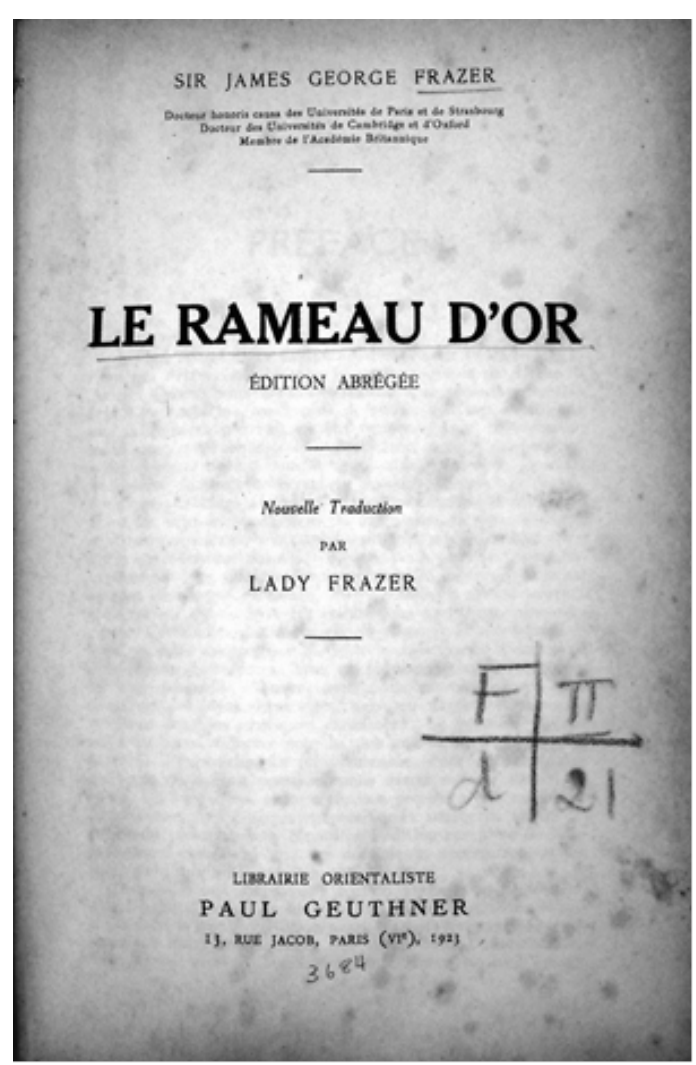

Contracapa da edição de Le Rameau d'Or pertencente a Mário de Andrade (IEB-USP)

Ora, a "Flor nacional" de Mário de Andrade situa-se, também, em uma versão do mito de Perséfone cuja violência e imprevisibilidade são sobrepostas pela valorização da forma, quando torna o "belo" o elemento preponderante na determinação da alegoria nacional. Nem a duplicidade da flor, entre a sedução e o perigo, que muito relembra as aproximações de modernistas como Victor Brecheret, Abguar Bastos, Augusto Frederico Schmidt e Raúl Bopp da floresta amazônica, nem as referências ao culto de Perséfone significariam um retorno ao matriarcado, pois Andrade encontrará em Dioniso (ou no boi) a figura contraposta, como se verá por suas marcas de leitura em $O$ ramo de ouro.

${ }^{17}$ MENDES, Murilo. Formação de discoteca, op. cit., p. 89. 
O VERDE, O BOI, O NÓ

É justo nos bailados mais próximos das culturas primitivas, nos Congos de origem negra, nos caboclinhos de inspiração ameríndia, e nos reisados e cordões de bichos de sobrevivência do culto animal, que se dá morte e ressureição. A importância do boi na vida brasileira, do chefe no organismo tribal, da mourama na conquista de terras, deu ao boi, ao chefe, ao mouro, um valor místico, um valor religioso, esotérico às vezes, e sempre simbólico, que foi o convite à criação das danças dramáticas. Foi a finalidade religiosa que deu aos bailados a sua origem primeira e interessada, a sua razão de ser psicológica e a sua tradicionalização.

Danças dramáticas do Brasil, Mário de Andrade (grifo nosso)

Valendo-se da antropologia de Sir James Frazer, os intelectuais modernistas recorreram às metáforas e aos mitos vegetais (como o de Dioniso e o de Perséfone) em uma tentativa de buscar um antecedente comum - o boi, o totem - que pudesse estabelecer a identidade nacional pela via da analogia, ou seja, por meio daquilo que se oferece na superfície e constitui, metaforicamente, a semelhança entre os seres. A passagem pelas marcas da leitura de $O$ ramo de ouro pretende demonstrar como Andrade sobrepõe em seu projeto de reativar e reunir o legado do folclore brasileiro uma perspectiva da origem como o retorno da essência, além de suscitar uma distinção entre o seu projeto poético literário, vanguardista, e a crença na responsabilidade política de sua atividade de intelectual.

Como se sabe, Frazer publica os dois primeiros volumes de 0 ramo de ouro em 1890, expandidos em 12 tomos entre os anos de 1907 e 1915, para somente em 1922 tornar-se conhecida a primeira versão abreviada. ${ }^{18}$ Escrita no momento de declínio do período vitoriano inglês (na transição entre os séculos $X I X$ e $X X$ ), marcado, ainda, pelo imperialismo britânico, essa obra transparece uma perspectiva regressiva do tempo, característica da sobrevivência, ao lançar o olhar sobre um "passado" - o da mitologia greco-romana, o dos rituais e costumes da antiguidade - para tratar dos povos primitivos a partir de relatos etnográficos esboçados no presente do antropólogo.

Em 1929, Mário de Andrade dá início à leitura do seu exemplar de O ramo

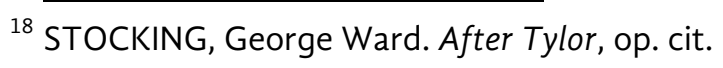


de ouro ${ }^{19}$, uma tradução ao francês da versão abreviada, a qual Ihe fora recomendada bem mais tarde pelo folclorista Luiz Saia. ${ }^{20}$ A partir de então, Frazer (além de Theodor Koch-Grünberg e do General Couto de Magalhães) ${ }^{21}$ Ihe servirá de bibliografia às elaborações acerca do folclore e do primitivo, como se pode ver em alguns dos vestígios deixados pelo livro do antropólogo escocês em Danças dramáticas do Brasil, cuja edição póstuma, organizada por Oneyda Alvarenga, é de 1959. As Danças aproveitam parte da pesquisa para a obra monumental que o autor pretendia elaborar, o manuscrito intitulado $\mathrm{Na}$ pancada do ganzá, ou seja, os documentos recolhidos nas viagens etnográficas pelo Brasil, e somente ganham uma versão mais próxima da definitiva em um volume datado por ele entre os anos de 1934 e $1942 .^{22}$

As danças colecionadas por Andrade seguem três correntes principais (a africana, a ibérica e a ameríndia) e derivam de três tradições básicas - os cortejos, os vilhacianos religiosos e os brinquedos populares ibéricos - de origens distintas, embora movidas por um impulso comum. O primitivo aparece, nessa obra, como aquele que, "desprovido das defesas da técnica", utiliza a magia para atuar na natureza e no ambiente ao seu redor - nos animais, minerais, vegetais, os quais possuiriam uma força superior à dele. Movido tanto pela "imperfeição técnica" como pelo "temor supersticioso", emprega o procedimento da magia homeopática para se apropriar, "domar" e "exorcizar" as forças naturais, presentes no "culto do vegetal, da primavera, Perséfone, o totem" e na "noção de morte e ressurreição da terra, do sol, do boi, do bicho, do vegetal, do deus". ${ }^{23}$

Portanto, o primitivo consiste em uma figuração da origem, uma sobrevivência do verde, interpretado como o retorno de uma tradição popular, proveniente especialmente de regiões menos abastadas como o Nordeste, em que figura como a esperança da colheita, mesmo com as condições climáticas adversas e que a cultura oficial procure sobrepor-se à popular. Essa noção que

${ }^{19}$ FRAZER, James. Le Rameau d'Or. Trad. Lily Frazer. Paris: Paul Geuthner, 1923.

${ }^{20}$ Segundo a informação do Projeto Marginália do IEB, a leitura da obra de Frazer foi sugerida por Luiz Saia, membro da Sociedade de Etnografia e Folclore, como bibliografia para a pesquisa de Andrade sobre os ex-votos do Nordeste. Notas de Luiz Saia no livro Le Rameau d'Or enviado a Mário de Andrade. MA: F/II/d/21. ANDRADE, Mário de. Bumba do Rio Grande do Norte (Bom Jardim). Documento transcrito dos originais manuscritos (autógrafos e datiloscritos) de Mário de Andrade. IEB/USP/FMA/MMA-Cx 39 (1). São Paulo, 1926.

${ }^{21}$ Cf. LOPEZ, Telê P. A. Mário de Andrade. Ramais e caminho. São Paulo: Duas Cidades, 1972.

${ }^{22}$ Cf. ALVARENGA, Oneyda. Introdução. In: ANDRADE, Mário de. Danças dramáticas do Brasil. Org., intr. e notas de Oneyda Alvarenga. 2. ed. Belo Horizonte: Itatiaia, 2002.

${ }^{23}$ ANDRADE, Mário de. Táxi e crônicas no Diário Nacional, op. cit., p. 32. 
se manifesta já em $O$ turista aprendiz, em que percebia as manifestações folclóricas do boi como parte do culto solar animista, investigado por Edward Burnett Tylor, é substituído, durante o processo de organização das Danças dramáticas, pelo culto de Perséfone. A mudança pode ser constatada pelo seu exemplar de $O$ ramo de ouro, em que escreve: "(1) Mostrar pois que o culto do Boi, no Bumba, não tem nada que ver com os bois do culto solar e outras bobagens. É a transformação do culto vegetal em culto animal." ${ }^{24}$ Para Mário de Andrade, a permanência da primavera (da vitória-régia brasileira) se dá no emprego da expressão "verde" e nos seus desdobramentos diversos - os galhos, ramalhetes, flores e ervas - nas cantigas das danças do boi.

As melodias do boi, deixadas por Andrade e transcritas por Alvarenga, pertencem ao terceiro tomo do livro e foram classificadas inicialmente como "Danças dramáticas colhidas do sul" e Bumba-meu-boi; as letras e partituras são provenientes, dentre outros estados, do Rio Grande do Norte (musicalizadas por Antônio Bento de Araújo Lima, Vilemão da Trindade e João Sardinha), de Pernambuco e de Vassouras, no Rio de Janeiro.

Segundo constata-se em "Reisado, Bumba-meu-boi e Pastoris", de Amadeu Amaral, estampado na Revista do Arquivo Municipal em 1940, existem duas variantes do boi que demonstram, de fato, uma semelhança com o episódio de "caça ao homem selvagem", como mencionara Mário de Andrade em nota deixada na obra de Frazer. ${ }^{25}$ No fragmento correspondente à observação, o antropólogo escocês trata do Pentecostes na Saxônia e na Turíngia

${ }^{24}$ ANDRADE, Mário de. In: FRAZER, James. Le Rameau d'Or, op. cit., p. 282.

${ }^{25} \mathrm{O}$ texto de Amaral é reproduzido por Luís da Câmara Cascudo em Antologia do Folclore Brasileiro (1944). Segundo o autor, em Flores e Triunfo, Pernambuco, os reisados têm como principais personagens o Rei (com a sua coroa de espelhos e vestuário de lata), a Burrinha (feita de balaio, com uma cabeça de burro), Ema (com saia armada e cabeça de madeira), os Mateus (pretos ou caboclos, com máscaras de carnaval, barbas e bigodes grandes) e o boi, cujo esqueleto deve ser feito de cipó para sustentar uma cabeça de verdade, com os chifres. $\mathrm{O}$ cenário é o de uma sala grande enfeitada com bandeiras, onde entram as personagens dançando junto ao Rei silencioso. Aparece, então, um emissário que comunica ao Rei que haverá uma guerra, que acontece durante o canto das personagens. O Boi apresenta-se finalmente dançando e confrontando os Mateus; um deles, bate na cabeça do animal que deve fingir-se de morto. Aparecerá o Médico que introduz a sua mão debaixo da cauda do Boi, de onde retira um embrulho de lenços que joga para a assistência, que lhes amarrará dinheiro antes de retorná-los. Por fim, as figuras cantarão para ressuscitar o Boi. Já no município de Guimarães, Maranhão, o boi tem o fígado roubado para alimentar a gestante Catarina, esposa do "pai Francisco" e, depois de uma discussão entre as demais personagens em busca do culpado pela morte do animal, reanimado pelo Médico. Cf. AMARAL JR., Amadeu. Reisado, Bumba-meu-boi e Pastoris. In: CASCUDO, Luís da Câmara. Antologia do folclore brasileiro. 4. ed. São Paulo: Martins, 1971. 
(Alemanha), onde havia uma cerimônia chamada "caça ao homem selvagem do arbusto / bosque" ("chasing the wild man out of the bush / wood"). Essa consistia em cobrir um jovem com folhas ou musgo, o qual, após esconder-se na floresta, seria perseguido por outros rapazes. $O$ "homem selvagem" recebia tiros de festim e, então, fingia-se de morto, até que fosse "curado" ao receber uma falsa sangria de outra personagem.

As manifestações do Boi do Rio Grande do Norte têm início com a entoação de coros de abertura, que atuam como um convite ao público para que veja a apresentação na praça: "(2) "Ôh de casa! Ôh de fora! / Mangerona quem 'stá aí! / Ou é o cravo ou é a rosa, / Ou a flô do bugarí." ${ }^{26}$ O boi é, então, oferecido por Mateus (personagem corpulenta, que portava um chocaIho) ao dono da casa, o "sinhozinho". Na "Primeira loa do contramestre", ainda na mesma variante, o sol colore a paisagem para o trabalho e ilumina as flores ao nascer do dia: "Pèrdi tudo quanto fiz / Cum a minha mão direita! / Nasce o Só pintando flores / Na mais dilicada rama, / Pidindo graças ao dia / Pra vê a luiz de quem ama [...]". ${ }^{27}$

$\mathrm{Na}$ variante de Bom Jardim, há uma passagem em que Mateus e Birico (personagem fantasiada de felino, não se sabe se leão ou gato) recolhem dinheiro do público, e quando entoam uma cantiga em cuja letra o nascimento da Virgem Maria figura no papel da ninfa Perséfone, segue também a lógica vegetal: "Do tronco nasceu a rama, / da rama nasceu a flô / Da flô é que nasceu Maria, - Ôh meu Deus! — Mãi de nosso Redentô". ${ }^{28}$

O amarrilho mágico, explorado por Frazer em $O$ ramo de ouro e, antes dele, por Edward Burnett Tylor, o fundador da antropologia social inglesa, em A cultura primitiva (1890), aparece ora como a sobrevivência de superstições diversas, ora segundo o princípio de exorcizar da magia negra e da feitiçaria. Em linhas gerais, no livro de Frazer o amarrilho consistia em uma estratégia para se controlar a natureza, fazendo o vento soprar para dar novamente movimento às embarcações estagnadas. Os magos finlandeses, de acordo com Frazer, vendiam ventos presos em três nós para os marinheiros: quando o primeiro era desfeito, libertava-se um vento moderado; caso se desfizesse o segundo, se daria um vendaval e, se fosse o terceiro, um furacão. ${ }^{29}$

\footnotetext{
${ }^{26}$ ANDRADE, Mário de. Danças dramáticas do Brasil., op. cit., p. 569.

27 Ibidem, p. 579.

${ }^{28}$ Ibidem, p. 590.

${ }^{29}$ FRAZER, James. Le Rameau d'Or, op. cit.
} 
De acordo com Tylor, o nó também pode ser visto como um procedimento de magia simpática, a imitativa, a que se funda na analogia entre dois seres. Assim, na tradução ao francês de $A$ cultura primitiva que pertencia a Mário de Andrade, o leitor escreve na página 138 do primeiro tomo o seguinte comentário: "Princípio do nó amarradas [sic]" ao qual acrescenta a seguinte nota de rodapé: "(1) Ver pg 137 os processos da corda", referindo-se ao seguinte fragmento, destacado do seu exemplar:

Do mesmo modo, o vidente moderno pretende sentir, por simpatia, as sensações de uma pessoa ausente e comunicar-se com ela através de uma mecha de seu cabelo ou de qualquer outro objeto que tenha entrado em contato com ela. A ideia de juntar dois objetos com uma corda para estabelecer uma comunicação material ou moral foi colocada em prática em diferentes partes do mundo. ${ }^{30}$

O fragmento pertence ao capítulo em que Tylor trata da sobrevivência na cultura e analisa princípios da bruxaria. Assim como os negros se valiam dos fetiches ou das roupas usadas por um doente para curá-lo, o clarividente moderno transmite a sua mensagem aos mortos utilizando as mechas dos cadáveres, a corda procura manter unidos objetos distintos mesmo a distância, criando, assim, uma sorte de série. Isso se daria, por exemplo, quando um feiticeiro aspira a ferida de um doente na Austrália ou situa um novelo sobre a casa do inimigo para sugar o sangue dele. Outro exemplo é o do ritual de sacrifício da rena em Ostyak, o qual consiste em amarrar uma linha entre o animal ofertado e o indivíduo enfermo, garantindo, desse modo, o efeito desejado. $^{31}$

Nas danças do boi o amarrilho imita, pelo processo, a necessidade de se atrair laços matrimoniais às moças. Nas cantigas-de-roda de Isidora, a mulher do gigante (Isidora Maria da Conceição Pia), deixada a sós pelo boi, dá nós em fitas da cor verde com esse objetivo: “(2) Dei um nó na fita verde, / E outro na verde fita, / Tenho ôtro pra dá, / - Ôh mana! - / Na morena mais bunita!”32; "(3) Deu um nó na fita verde / E outro na verde rama, / Tenho outro pra dá, / - Ôh mana! - / Na morena que me ama!"33. Além disso, ainda nas cantigas-de-roda de Isidora, a superstição aparece associada igualmente a

30 TYLOR, Sir Edward Burnett. La Civilisation Primitive. Trad. Pauline Brunet. Paris: Ancienne Librairie Schleicher, 1920, p. 137.

${ }^{31}$ Ibidem.

${ }^{32}$ ANDRADE, Mário de. Danças dramáticas do Brasil., op. cit., p. 602.

${ }^{33}$ Ibidem, p. 602. 
uma tentativa de apreender o tempo com a fita, para estender o dia: "Eu só quiria pudê / Fazê o dia maió, / Dava um nó na fita verde, / Prendia o raio do Só, / láiá! / (Refrão)". ${ }^{34}$

Já no Bumba-meu-boi de Pernambuco existe algumas figuras singulares que, embora não sejam descritas com a mesma cor, personificam a aparência vegetal. É o caso do "pinicapau", cuja fantasia consiste em "um tambor de esteira com um pano branco no lugar da pele", onde um homem se esconde; "do meio do pano sai pro alto", ainda, "um pau em que um passarinho, Pinicapau, de pano sobe e desce aos pulinhos". ${ }^{35}$ Além disso, o verde torna a aparecer nas canções da "Segunda despedida", a qual sucede o funeral do boi, ora se tornando a cor que refresca o calor do sertão - (9) "Quando eu vim de Goianinha, / Vinha morrendo de sede, / Lavandêra me deu agua, / No gômo da cana verde." ${ }^{36}$ - , ora significando o engano da esperança, uma frustração: “(8) De que serve um pingo dagua / Dento dum rio corrente / De que serve um amô firme / Fóra da vista da gente // Tudo que é verde no mundo / Eu desejava queimáa, / O verde é isperança, / Tô cansado de isperáa!". ${ }^{37}$

A presença do culto vegetal, segundo demonstram os documentos recolhidos por Andrade e as observações deixadas no livro de Frazer, pode referir-se a um elemento de resistência político-social das massas. Na América Latina, o escritor dialoga com o estudioso nicaraguense Pablo Antonio Cuadra, quem publica, no Boletín del Folklore do Instituto de Cooperação Universitária de Buenos Aires, o texto "Horizonte patriótico do folclore" (1940). ${ }^{38}$ Cuadra defende, assim como Andrade, que esse saber deva emergir contra os contextos políticos que minam ou encobrem o elemento popular.

Entre 1942 e 1945, o autor das Danças redige um pequeno texto para o Manual bibliográfico de estudos brasileiros, organizado por William Berrier e Rubem Borba de Moraes, o qual, em decorrência da grande guerra e do bombardeio de Pearl Harbor, é somente publicado em 1949. No panorama sobre o estatuto dos estudos folclóricos no Brasil, Andrade distingue-os da literatura e

34 Ibidem, p. 603.

35 Ibidem, p. 644.

${ }^{36}$ Ibidem, p. 667.

${ }^{37}$ Ibidem, p. 667.

${ }^{38}$ CUADRA, Antonio Pablo. Horizonte patriótico del Folklore. Boletín del Folklore. Departamento de Folklore del Instituto de Cooperación Universitaria, Buenos Aires, n. 2, p. 14-23, 1940. Esse texto está marcado com a observação "verde", como o livro de Frazer e A cultura primitiva de Tylor, anotação situada ao lado de um fragmento do Cancioneiro de romances (Cancionero de romances, 1550) de Martín Nuncio. Agradeço a Raúl Antelo pelo documento. 
demonstra a preocupação de torná-los uma ciência. Sendo parte de um volume que participava de um projeto de união pan-americanista, afirma ser “imprescindível uma conceituação nova de folclore para os povos da civilização e cultura recentemente importada e histórica, como as da nossa América". ${ }^{39} \mathrm{O}$ intuito do autor seria, ainda, o de delimitar critérios seguros para abranger as manifestações que serviriam para documentar o folclore nacional e distingui-lo do fato popularesco, além de evitar que fosse considerado meramente uma "forma burguesa" de conhecimento "voltada à apreciação das classes superiores". 40

Na mesma época, Antonio Gramsci (1891-1937), sugerira que o folclore permitiria equilibrar a alta e a baixa cultura - a primeira organizada e coerente, e a segunda caoticamente estratificada, anacrônica e subserviente com relação às classes dominantes. Ele propunha, em Literatura e vida nacional (1950), a hegemonia da expressão popular e se opunha à idealização romântica e à exaltação do caráter pitoresco a ela atribuídas. O folclore progressivo gramsciano, retomado pelo seu herdeiro Ernesto de Martino, estranhamente, como uma alternativa ao naturalismo da antropologia anglo-saxã, conserva características da doutrina das sobrevivências, pois compõe-se de dois elementos temporais heterogêneos, um tradicional e estagnado e o outro em circulação:

Também nesta esfera deve-se distinguir diversos estratos: os fossilizados, que refletem condições de vida passada e que são uma série de inovações frequentemente criadoras e progressistas, espontaneamente determinadas por formas $e$ condições de vida em processo de desenvolvimento e que estão em contradição (ou apenas diferentes) com a moral dos estratos dirigentes. ${ }^{41}$

Não é fortuito que, no texto no Manual bibliográfico, Andrade afirmasse que o folclore tenha se voltado no Brasil para as classes superiores, demonstrando uma afinidade com o pensamento de Antonio Gramsci. Para Ernesto de Martino, quem retoma o debate nos anos 1940, os elementos arcaicos deveriam emergir na elaboração política do futuro. $E$, naquele contexto, a esquerda trabalhava a hipótese de uma "democracia progressiva" impulsionada

39 ANDRADE, Mário de. Folclore. In: MORAES, Rubens Borba de; BERRIEN, William. Manual bibliográfico de estudos brasileiros, v. 1. Brasília: Senado Federal, 1998, p. 442.

40 Ibidem, p. 423.

${ }^{41}$ GRAMSCI, Antonio. Literatura e vida nacional. 3. ed. Trad. Carlos Nelson Coutinho. São Paulo: Civilização Brasileira, 1986, p. 185, grifo nosso. 
pela ascensão das revoltas camponesas no sul do país e pela Frente Democrática Popular (PCI-PSI), derrotada nas eleições presidenciais pela Democracia Cristã (DC) na Itália. O folclore poderia, assim, funcionar como uma voz atual que rompe com as formas tradicionais. Essa voz, no entanto, parte de um povo que se constitui como aquilo que não apresenta com a nação uma relação de pertencimento, mas se manifesta como uma "crise de presença", pois estaria parcialmente submerso na cultura, entre a corola e as raízes de uma flor. Sendo assim, o povo não se exprime enquanto essência, mas na sua qualidade de estar sempre pululando, prestes a desaparecer sem deixar pegadas. De Martino estaria em consonância com uma leitura possível da sobrevivência como a permanência de um sintoma - perscrutado na repetição de gestos enfermos e de um discurso, fantasioso, impotente de se referir à realidade. Desse modo, pode-se entender a razão para de Martino ter se interessado pelo sul do país como a terra de um pathos primitivo, do irracional e da morte. Nessa região a tarantela surge como fenômeno cultural em que os dançarinos executam a sua performance sem a plena consciência dos movimentos, bailando ao som de instrumentos musicais que os colocam em um delírio frenético, em um entusiasmo quase epilético, em que o ser, sem que esteja presente, transporta para os seus gestos os sintomas do tarantismo, enfermidade de causas desconhecidas adquirida em outro tempo. ${ }^{42}$

Por sua vez, para Mário de Andrade, o povo é o elemento base da nação - é forma e linguagem, como a vitória-régia - cuja inserção no Estado seria assegurada pelo emparelhamento do serviço do intelectual com o governo, de acordo com a atitude dominante no modernismo brasileiro. Por esse motivo, a institucionalização do folclore vem acompanhada pela criação de diversos órgãos, como o Departamento da Cultura da Municipalidade de São Paulo, em 1935, a Sociedade de Etnografia e Folclore, vinculada ao Departamento, e o Serviço do Patrimônio Histórico e Artístico Nacional, inaugurado em 1937. Em especial, os dois primeiros estariam colaborando com o intuito defendido por Mário de Andrade no texto para o Manual bibliográfico, pois ao Departamento de Cultura se vinculam a Revista do Arquivo e a Discoteca Pública, onde estavam reproduzidas canções e danças populares catalogadas por Mário enquanto dirigia essa instituição. Não por acaso, a Universidade de São Paulo, também derivada dessa época, se vale de uma crítica literária atrelada a alguns

\footnotetext{
${ }^{42}$ MARTINO, Ernesto de. The Land of Remorse. A Study of Southern Italian Tarantism. Trad. e notas Dorothy Louise Zinn. London: Free Association Books, 2005.
} 
dos valores defendidos pelo modernismo brasileiro, como o apelo nacionalista desse movimento, o enfoque no engajamento social da arte e da literatura a partir de 1930 e a determinação da Semana de Arte Moderna como marco inaugural da vanguarda. ${ }^{43}$ Nesse sentido, poderíamos sugerir que, ao favorecer um discurso autonomista acerca da literatura, a crítica do modernismo por vezes confunde a fundação das ideias com o julgamento das obras, o que teria como consequência a produção de textos que se tornam uma paráfrase dos objetos analisados e privilegiam a perpetuação de um momento histórico, em detrimento da abertura da interpretação. Seria contra esses aspectos da crítica literária e da estética que Carl Einstein se opunha com a sua proposta do absoluto na arte. Como vimos, o historiador da arte alemão percebia, em "Rouxinol", a predominância de um discurso congelado que valoriza a independência do objeto literário e a materialização do texto, ao passo que ele se insurgia, por sua vez, contra a hierarquia da forma.

Mário de Andrade mostra-se muito mais afeito a um modelo de intelectual que estabelece uma relação de interioridade com o Estado como grande parte dos modernistas, entre os quais poderíamos citar Carlos Drummond de Andrade e Cecília Meireles, a qual também se mobilizara em favor do folclore brasileiro, e muitos outros. Daí que o nó funcione, em certo sentido, como uma sorte de "mecanismo de captura", do qual nem mesmo o trabalho

\footnotetext{
${ }^{43}$ Poderíamos citar dois exemplos nesse sentido, reconhecendo que, naturalmente, a afirmação acima não poderia homogeneizar o pensamento produzido na Universidade de São Paulo e sequer a obra dos autores mencionados nesta nota. Devemos acrescentar, todavia, que um caso emblemático é o de Antonio Candido no ensaio "Literatura e subdesenvolvimento" (publicado em Cahiers d'Histoire Mondiale, da UNESCO, em 1970 e, em 1973, no primeiro número da revista Argumento), em que o autor, concebendo o nacionalismo do movimento modernista como uma necessidade de conscientização social, relaciona a consciência do subdesenvolvimento do Brasil à produção literária de cada período, mostrando a herança lukacsiana intrincada em sua reflexão. Candido caracteriza a noção de país novo (que iria até o decênio de 1930) e de país subdesenvolvido estabelecida por Mário Vieira de Mello para a América Latina. Na literatura, o estatuto de país novo provocou interesse pelo lado exótico do Brasil e conferiu ao modernismo a "pré-consciência" do estágio de subdesenvolvimento do país, enquanto no nacionalismo compensatório do romantismo tinha-se apenas, para Candido, uma consciência amena do atraso. Já Luiz Lafetá, em 1930: A crítica e o modernismo (São Paulo: Duas Cidades, 1974), defende a existência de um projeto ideológico, o qual havia sido almejado por Mário de Andrade, por trás do projeto estético do modernismo, voltado às alterações na linguagem literária. Para Lafetá, o decênio de 1930, sobre o qual recai o seu foco, foi a época de "amadurecimento" do modernismo, período no qual, já tendo lançado a semente para as inovações na linguagem, pela aproximação entre a escrita e a fala, por exemplo e, tendo publicado algumas de suas maiores obras (como Macunaíma, de 1928 e Memórias sentimentais de João Miramar, 1924), os modernistas passaram a refletir sobre os efeitos da vanguarda e voltaram-se para as modificações que se faziam urgentes na sociedade, aliando a crítica social à revolução da linguagem.
} 
intelectual pode escapar, pois a relação de independência que estabelece com o governo é somente ilusória. Embora o Estado busque uma definição por meio da interioridade e pela produção de um modelo, ele não se caracteriza, contudo, pela ideia de chefe como parece supor Mário de Andrade, mas por sua perpetuação em órgãos de poder e pela tentativa de produzir uma homogeneidade por meio da identidade. ${ }^{44} \mathrm{O}$ reconhecimento dessa impossibilidade resulta, para Mário, no abandono involuntário de alguns dos seus projetos (como o das Danças dramáticas), na entrega com pouco gosto ao trabalho na espécie de exílio que viveu no Rio de Janeiro, após o Partido Democrático ter saído do poder e Getúlio Vargas assumi-lo, e na vida pouco regrada que lhe debilitou a saúde a partir de então. ${ }^{45}$

O nó pode ser compreendido, ainda, como um elemento que sugeriria a necessidade de se delimitar a unidade nacional, seja pela via da transcendência ou da representabilidade do povo. Na introdução às Danças dramáticas, o autor assegura a presença de um elemento "inexplicável" nas danças, o qual traria a simbologia necessária "para se compreender a permanência de certas tradições de realidades distintas, na Coletividade" ${ }^{46}$ Isso porque, para o autor, "O deus, explicação mística sim, é permanente, solúvel, porque pelo seu mistério e imensa vacuidade se presta pra justificar qualquer variante dum fenômeno vital. ${ }^{\prime 47}$ Vale recordar, ainda, que existem diversos indícios deixados por Mário de Andrade no exemplar de $O$ ramo de ouro que apontam para uma interpretação do boi como chefe de governo, seja por meio da anotação de expressões como "Imperador - proclamação", "Bumba" 48, "fogo Bumba" ${ }^{49}$, "Imperador criança" ${ }^{50}$, ou simplesmente "imperador".

O Dioniso marioandradiano, apesar de sua recusa aos mitos solares, patriarcais, ainda busca a união comunitária e, por isso, a finalidade primordial que Andrade recupera nas Danças é, como vimos, a religiosa. Não nos esqueçamos

${ }^{44}$ Cf. DELEUZE, Gilles; GUATTARI, Félix. Mil platôs. Capitalismo e esquizofrenia, v. 5. Trad. Peter Pál Pelbart. São Paulo: Editora 34, 2005.

${ }^{45}$ Cf. DUARTE, Paulo. Mário de Andrade por ele mesmo. Pref. Antonio Candido. 2. ed. São Paulo: Hucitec, 1977, e ANDRADE, Mário de. Cartas a Murilo Miranda (1934-1945). Rio de Janeiro: Nova Fronteira, 1981.

${ }^{46}$ ANDRADE, Mário de. Danças dramáticas do Brasil, op. cit., p. 71.

${ }^{47}$ Ibidem, p. 33.

${ }^{48}$ ANDRADE, Mário de. In: FRAZER, James. Le Rameau d'Or, op. cit., p. 119.

${ }^{49}$ Ibidem, p. 186.

${ }^{50}$ Ibidem, p. 120. Possivelmente, Mário de Andrade se referisse, ainda, à Festa do Divino, que, segundo Amadeu Amaral, trata-se da única comemoração onde encontramos "Rei e Rainha", "Imperador e Imperatriz". AMARAL JR., Amadeu. Reisado, Bumba-meu-boi e Pastoris, op. cit. 
de que a palavra religião permite, etimologicamente, duas interpretações. A primeira delas indica a sua proveniência do termo religare, ou seja, "religar", amarrar através de um vínculo os homens aos deuses, sentido escolhido, por exemplo, por Jean-Jacques Rousseau e reforçado pelo cristianismo. A segunda deriva da compreensão da religião como relegere, o que significa a hesitação perante as formas divinas e que a relação entre os deuses e os homens não é imposta por uma característica comum (os homens criados à semelhança da imagem de Deus), mas por um contrato e pela confiança em si mesmos. ${ }^{51}$ Andrade inclina-se ao primeiro sentido, assumindo que o comunitário sustenta-se sobre uma unidade estabelecida pelo vínculo místico e pela linguagem, por um fundamento de verdade que reúne os seres e que se manifesta na arte. Essa deixa de ser, portanto, imanente e absoluta, para exprimir com os meios de que vale - a língua, a dança, os gestos, as imagens, a matéria - o fortalecimento e a homogeneização desses laços, o intuito desse autor de recuperar a tradição popular e regulamentá-la pelas instituições do homem civilizado.

${ }^{51}$ NANCY, Jean-Luc. La comunidad enfrentada. Trad. J. M. Garrido. Buenos Aires: La Cebra, 2007. 